В рамках дослідження проведено аналіз міжнародних нормативноправових документів з управління ризиками в галузі охорони прачі та виявлено наступні недоліки:

- невизначеність иілей управління ризиками;

- складність виконання відповідної процедури та ї необтрунтованість;

- відсутність наявних підходів до можливості оптимального управління ризиками з урахуванням ресурсних можливостей суб'єкта господарювання.

Зазначено, що одним з основних способів управління професійними ризиками є перерозподіл фінансових ресурсів підприємства. Але наявного методологічного інструментарію для реалізації даного способу за результатами аналізу не виявлено.

3 метою вирішення зазначеної актуальної проблеми, розроблено метод оптимального управління професійними ризиками. Метод розроблено на основі побудови оптимізаційних моделей за критеріями мінімізації середніх очікуваних загальних витрат підприємства на охорону праці. Зазначено, що икідливі виробничі фактори діють з випадковою інтенсивністю в межах робочої зони протягом даного періоду часу. A ризик вимірюеться ймовірністю перевищення допустимої концентрацій (рівнів) визначених факторів, що діють у робочому просторі, а також відповідними наслідками. Змінними розроблених моделей є витрати підприємства на заходи, що пов'язані із забезпеченням безпечних та здорових умов праці. Сформульовані пряма та зворотна задачі оптимізації, які зведені до деяких завдань опуклого програмування. Пряма задача полягає у мінімізації ймовірності настання ризикової події при заданому обмеженні на загальні витрати на охорону пращі. А зворотна - як мінімізація середніх витрат на профілактику та ліквідацію наслідків наступу ризику перевищення гранично допустимої концентрацї̈ (рівня) при обмеженні на ймовірність наступу такого перевищення.

Розрахунок моделей визначив залежність, що виражається у зменшені припустимої ймовірності настання ризикової подї, при збільшенні витрат на охорону праці. Це дозволяє рекомендувати метод для використання суб'єктами господарювання у міжнародному форматі

Ключові слова: професійний ризик, гігієна прачі, управління ризиком, опукле програмування, професійні захворювання
UDC 331.47

DOI: $10.15587 / 1729-4061.2018 .132596$

DEVELOPMENT OF THE METHOD FOR THE OPTIMAL MANAGEMENT OF

\section{OCCUPATIONAL RISKS}

\author{
A. B och k ov sk y i \\ $\mathrm{PhD}$, Associate Professor* \\ V. Gogunski i \\ Doctor of Technical Sciences, \\ Professor* \\ E-mail: vgog@i.ua \\ *Department of Systems \\ Management Life Safety \\ Odessa National Polytechnic \\ University \\ Shevchenka ave., 1, Odessa,
}

Ukraine, 65044

\section{Introduction}

A key requirement of the Framework Directive of EU No. 89/391/EEC is to ensure safety and occupational health of workers when they perform occupational activity [1]. It is a duty of every employer, regardless of the form of ownership of an enterprise and its industrial purpose. In the context of performance of his duties, an employer must create and ensure functioning of the occupational safety management system within the framework of an enterprise (organization). The occupational safety management system (OSMS) is an integral part of the enterprise management system, aimed at prevention of accidents, occupational diseases, and production injuries. These phenomena are directly related to the influence of dangerous and harmful production factors on a human, the time of occurrence of which, intensity, duration, etc. are rather difficult to predict. This is explained by stochastic nature of certain factors and random dynamics of changes of characteristics and states of these factors over time. It is only possible to speak about the probability of this impact and a certain severity of its consequences for an employee, that is, about the risk of hazards [2,3]. Hence, the process of management of these risks must be implemented in the framework of the OSMS functioning.

The modern global risk management strategy is based on the principles of hazards prevention $[4,5]$. The realization of these principles implies their consistent implementation of several stages, the main of which are:

- identification of potential hazards;

- assessment of risks of occurrence of hazards;

- development and implementation of security measures;

- monitoring and audit of risks.

The procedure of consistent and cyclic implementation of these stages can be regarded as the process of management of hazard occurrence risks. Each stage of the management process is quite complex and requires a certain amount of resources for its implementation (financial, human, methodological, etc.). It is evident that on condition of the proper performance of duties by participants, effectiveness of the management process will depend on the amount of resources that are allocated by an enterprise for its implementation.

The desired goal, which every company tries to achieve when implementing this process, is to attain zero level of the risk of hazards. But depending on the nature, quantity and characteristics of hazardous and harmful production 
factors, the amount of resources needed to achieve this goal, can exceed the capabilities of the world economy. Therefore, the purpose of a company is to achieve and maintain an acceptable risk level, which would match its economic capacities. That is, a relevant problem of the management process is to find an optimal balance between an acceptable risk level and available resources needed for its achievement and maintenance.

\section{Literature review and problem statement}

Risk management issues were examined in the studies [6-12] considered below.

Thus, in [6], based on the conducted analysis of statistical data, it was shown that several hazardous factors operate simultaneously in the workplace of an employee. This influence is considered to be integrated and requires a comprehensive assessment of occupational risks. In the framework of the study, combined approaches to occupational risks management were developed and the impact of such approaches on qualitative and quantitative indicators (working conditions, occupational diseases, etc.) was determined. The complex models, developed in the research, are based on the known techniques of risk evaluation and focus on the calculation of quantitative indicators for a specific range of harmful factors. However, the existing model does not take into consideration the dynamic characteristics of changes of states of harmful production factors over time, which is a drawback. Such changes constantly occur during actual functioning of the systems "human - machine - environment" and, as practice shows, are the main causes of occurrence of occupational hazards.

In paper [7], it was determined that due to existence of shortcomings of methodological support of the risk management process, about $25 \%$ of working places are dangerous. It was noted that some of the major unsolved problems of the risk management process are:

- non-optimal use of resources for occupational safety and health;

- mismatch between a methodological support and the level of awareness of executors;

- complexity of techniques, which leads to formalization of the management process, etc.

Based on the identified drawbacks, the original management technique was proposed, which makes it possible to redistribute financial resources for occupational safety and health between preliminarily ranked occupational risks. However, the indicated technique is based on expert findings, which makes it biased. The mechanism of interrelations between the level of an acceptable risk and necessary number of resources, required for its achievement and maintenance, was not developed within the framework of this technique. The development of the above-mentioned mechanism is necessary because, as a rule, the range of harmful production factors affecting an employee is wide, and the amount of resources to minimize them is limited.

Article [8] is devoted to the relevant problem of dynamic management of occupational risks. Such management, in accordance with the developed technique, is carried out online by using the influence of an operator on the parameters of a control system. The positive point of the technique is taking into consideration the dynamic component of the influence of harmful industrial factors on an employee in time and space. However, practical implementation of the specified technique is only possible at large enterprises with a significant amount of human and financial resources since it is necessary to implement a branched automated system with constant presence of a human-operator in order to manage this process. A high resource consumption, which prevents its use in the practice of most business entities (small and medium-sized businesses), can be referred to the disadvantages of the proposed technique. Moreover, this technique does not apply the resource redistribution mechanism, which is one of the main ways to actual management of occupational risks.

Paper [9] discusses the problems of optimization of processes of environmental pollution risk management. In the framework of the research, the authors developed the method of optimal distribution of costs between environmental measures with the constraint for the established environmental quality level. The positive side of the method is considering recourse capacities of an enterprise during the quality control. However, the method was designed for management of environmental indicators, which is not the area of functioning of the occupational safety management systems.

In study [10], evolutionary aspects of the development of occupational safety systems were explored. It was noted that the complications of modern technical systems and randomness of hazard occurrence requires a new, dynamic approach to risk management, taking into consideration the economic aspect. The general block diagram of the dynamic risk management was presented, but the authors did not develop any specific methodological tools for practical application of this scheme, which is the main drawback of the work.

Paper [11] focuses on the known methods and models of management of hazard occurrence risks. The authors classified the methods and models, determined the tendencies of development of research into the risk management areas and the directions, by which it is advisable to conduct the studies in order to overcome existing problems. The material of the publication presents only the analytical reference, which is useful only as a theoretical foundation for improvement of the risk management procedure.

Article [12] stressed the need, based on the analysis of known risk management methods, of using a fundamentally new approach that takes into consideration a comprehensive analysis of both technical and social safety factors. A promising approach of risk management in the field of labor protection is supposed to be built, based on the application of the theory of systems. A new management structure - a system of analysis of stability of processes, which combines four aspects, was presented. These aspects include: preliminary detection of hazards, admissions with an error, flexibility, and ability for upgrading. Judging from the concept and principles of the system's operation, described by the authors of the study, it will make it possible to analyze the hazards that have certain stochastic dynamics. This is a positive point, because the risks of these hazards are most difficult to manage. The lack of a mathematical model of functioning of the system, which would take into consideration the criterion of availability of resources for optimal risk management, can be considered the drawback of the research.

Work [13] studies the management of risks, which are caused by harmful and hazardous factors of fire. The method was developed based on the classical methods of quantitative risk assessment. In the framework of the method, the mathematical model, which makes it possible to evaluate and manage risk in dynamics, was developed. However, this 
model considers not the dynamics of the influence of harmful industrial factors on an employee in time, but rather the speed of making managerial decisions. In addition, the results of the conducted experiments indicate that the management method and the specified model require corrections, since they do not take into consideration the full range of harmful factors.

One of the main ways of risk management in the field of occupational health and safety is redistribution of financial resources of an enterprise. Such redistribution must occur in the direction of more significant (in terms of the negative impact) ranked risks. Risk ranking occurs as a result of implementation of the process of their criterial evaluation, after which management-related decisions are made. It is clear that the management process should be based on the relevant scientifically grounded methodological basis in the form of mathematical models. In this context, these models should be directed to determining the minimum possible amount of financial resources that make it possible to maintain the level of acceptable occupational risk at an enterprise. The necessary condition of the adequacy of such models is considering randomness of characteristics of the influence the dangerous and harmful production factors on an employee in time since these characteristics are one of the main causes of occupational hazards [4].

From the analysis of the conducted studies, it is not known about existence of scientifically grounded methodological tools in the framework of which it would be possible to implement in practice the way of occupational risks management by means of optimal distribution of labor protection costs. Since under real conditions, this way is the most common, development of an appropriate method is one of the possible solutions to this problem.

\section{The aim and objectives of the study}

The aim of this research is to develop a method of optimal management of occupational risks at randomness of the influence of harmful industrial factors on an employee within working time.

To accomplish the aim, the following tasks have been set:

- to carry out the analysis of the international normative-legal documents on labor protection in the field of risk management;

- to interpret the components of the method of optimal management of occupational risks;

- to formalize the method of occupational risks management in the form of optimization of mathematical models with the view to determining the costs of an enterprise for minimize the expected consequences at facing risks;

- to perform quantitative assessment of the components of the total costs for occupational health and safety for a fixed range of harmful production factors by the methods of mathematical statistics.

\section{Construction of models for the optimal management of occupational risks}

Modern methodology of risk management in the field of occupational health and safety is regulated by the following current international standards:

- OHSAS 18001:2007. Occupational health and safety assessment systems;
- OHSAS 18002:2008. Occupational health and safety assessment systems. Basic principles of meeting requirements of OHSAS 18001:2007;

- ILO-OSH 2001. Occupational safety systems. General requirements;

- IEC/ISO 31010:2009. Risk management. Methods for general risk assessment;

- ISO Guide73:2009. Risk management. Dictionary of terms.

The main regulatory document that contains methodological foundations and tools of risk management is the international standard IEC/ISO 31010:2009 "Risk management. Methods for general risk assessment".

In the specified standard, the risk management procedure is proposed to be carried out with the help of 30 techniques, using them separately or in combinations. It is proposed to select the techniques in accordance with purposes, resource capacities of the business entity and the stages of the process. However, to have a possibility to implement the process according to the requirements of the standard, the business entity needs to solve three major problems.

The first of them is the uncertainty of objectives in risk management.

This problem is primarily associated with the lack of the relevant unified terminology for the concept of risk in appropriate normative-legal documents. In different standards, risk is associated with both a possible threat to life and health of a person, and with the material, and even environmental harm. This situation greatly complicates the problem of target of the resources, allocated for the implementation of the management process and, as a result, leads to non-optimal use of these resources.

The purpose of risk management in the field of occupational health and safety can be determined based on the definition of the appropriate term. According to the definition, occupational health and safety is a system of legal, socio-economic, organizational and technical, sanitary-hygienic and curative-preventive measures and ways, aimed at saving the life, health and working capability of a human in the process of labor activity.

Thus, the main purpose of risk management within functioning of occupational health and safety management systems is to preserve life, health and working capability of a human in the course of labor activity.

In the context of infliction of possible harm to a person, it is necessary to consider two types of risks, related to performance of work activities:

- risk of occupational hazards;

- occupational risk.

In the first case, one should consider the probability of inflicting production-related damage to human health, getting injures and death cases.

In the second case, one considers purely a risk of harm to human health, that is, the probability of getting occupational diseases. Occupational risks will be considered as a part of this study.

The second problem is complexity of performing the procedure of risk management in the framework of the existing standards and the fact that it was not scientifically grounded [15].

Thus, to have the possibility to implement each stage of the procedure, it is necessary to analyze and select one out of 20-25 techniques by uncertain criteria. These techniques are not described in detail in the standard, so to select the one that is necessary for the entity, it is necessary to have a good command of each of them, which is absurd. 
In addition, the procedure of management requires processing rather large arrays of information and complex mathematical calculations [15-17]. It is also impossible to do this without the help of techniques, adapted to the standard software, and the appropriate level of knowledge and competences. Therefore, in practice, the procedure of management of occupational risks, especially at small and medium-sized enterprises, is not implemented at all or is implemented formally.

And finally, the third problem is the lack of available approaches to the possibility of optimal risk management taking into consideration resource capacities of the business entity.

Although the regulatory standard indicates that the management process must be implemented according to existing resource capacities, there are no recommendations or tools how it is necessary to perform it.

In order to eliminate the identified problems, the method for optimal management of occupational risks based on mathematical models was developed in the framework of this research.

In the course of development of the model, the following designations of the main components were accepted:

(HPF) - harmful production factor;

$B_{1}-$ costs of the business entity for development and implementation of organizational and technical measures and means of protection against effect of $n$ kinds of HPF on an employee;

$B_{2}$ - costs of implementation of curative-preventive measures for elimination of consequences of HPF on an employee;

$B$ - total costs of the business entity for occupational health and safety;

$T$ - duration of a work shift.

$\omega_{i}$ - random intensity of the $i$-th HF on an employee;

$q_{i}$ - boundary permissible concentration (BPC) or boundary permissible level (BPL) of the $i$-th HF;

$P_{i}$ - financial resources, allocated by business entity to minimize the consequences of the effect of the $i$-th HF.

The actual excess of the boundary permissible value $q_{i}$ by the $i$-th HF is equal to:

$$
\Delta_{i}=\max \left(0, \omega_{i} T-q_{i}\right) .
$$

Let us designate through $F_{i}(y)$ the function of distribution of random magnitude $\omega_{i}$, that is

$$
F_{i}(y)=P\left\{\omega_{i} \leq y\right\}
$$

Then, according to (1) and (2), we obtain:

$$
\begin{aligned}
& \mathrm{P}\left\{\Delta_{i} \leq x\right\}=\mathrm{P}\left\{\omega_{i} T \leq q_{i}\right\}+\mathrm{P}\left\{q_{i}<\omega_{i} T \leq x+q_{i}\right\}= \\
& =\mathrm{P}\left\{\omega_{i} T \leq x+q_{i}\right\}=F_{i}\left(\frac{x+q_{i}}{T}\right), x \geq 0 .
\end{aligned}
$$

In this case, the mean value of a random magnitude $\Delta_{i}$, according to (3), is equal to:

$$
M \Delta_{i}=\int_{q_{i} / T}^{\infty}\left(y T-q_{i}\right) \mathrm{d} F_{i}(y),
$$

where $M$ is the symbol of mathematic expectation. We assume that average costs $\bar{B}_{2}$ for elimination of consequences for implementation of occupational risk $\left\{\omega_{i}>q_{i} / T\right\}$ are proportional to mathematic expectation $M \Delta_{i}$, that is:

$$
\bar{B}_{2 i}=k_{i} \mathrm{M} \Delta_{i},
$$

where $k_{i}$ is the cost for elimination of a unit of consequences.

Then at $B_{1 i}=P_{i}$ we obtain:

$$
\bar{B}=\sum_{i=1}^{n}\left(P_{i}+\bar{B}_{2 i}\right)
$$

Dependence $M \Delta_{i}$ on $P_{i}$ is generally speaking a certain non-increasing function, for example, it can take the following form:

$$
M \Delta_{i}=a_{i}\left(r_{i}+P_{i}\right)^{-b_{i}}, a_{i}, b_{i}>0
$$

where $r_{i}, a_{i}, b_{i}$ are the data that are determined by means of processing statistical data about actual excess of BPC (BPL) at correspondent costs, allocated for protective measures; $r_{i}$ is the specific costs for treatment of occupational disease (recovery from inflicted harm to an employee's health).

Based on (5)-(7), general costs for occupational safety of the entity can be presented in the form of:

$$
\bar{B}(\vec{P})=\sum_{i=1}^{n}\left[P_{i}+k_{i} a_{i}\left(r_{i}+P_{i}\right)^{-b_{i}}\right]
$$

where

$$
\vec{P}=\left(P_{1}, \ldots, P_{n}\right) .
$$

Safety level of an employee within a working shift can be quantitatively characterized as probability of non-occurrence of any risk event by all potentially possible HF. Probability of non-occurrence of an event with $n \mathrm{HF}$ is determined by the following dependence:

$$
V(\vec{P})=\prod_{i=1}^{n} F_{i}\left(q_{i} / T\right) \frac{\Delta y}{\Delta x} .
$$

The process of optimal management of occupational risks can be presented as a problem of maximization of function (9) at constraints:

$$
\sum_{i=1}^{n}\left[P_{i}+k_{i} a_{i}\left(r_{i}+P_{i}\right)^{-b_{i}}\right] \leq \Phi,
$$

where $\Phi$ is the magnitude of the amount of financial resources of the business entity for occupational safety of an employee within time $T$. Such statement of optimization problems will be called direct.

It is also possible to state a reverse problem, in particularly, to find vector $\vec{P}$, which minimizes function (8), at constraints (9):

$$
1-\prod_{i=1}^{n} F_{i}\left(q_{i} / T\right)=\varepsilon
$$

where $\varepsilon$ is the assigned small probability of hazard occurrence, which is assigned by the business entity (risk criterion)

For the simplest case of solving the direct and inverse optimization problems, we will accept a uniformed distribution law $F_{i}(y)$, that is: 


$$
F_{i}(x)=\left\{\begin{array}{l}
0, \text { at } x \leq 0, \\
\frac{x}{v_{i}}, \text { at } 0<x<v_{i}, \\
1, \text { at } x \geq v_{i},
\end{array}\right.
$$

where $v_{i}$ is the maximal possible intensity of the effect of the $i$-th harmful production factor on an employee in the working zone. Thus, according to (4), we obtain:

$$
M \Delta_{i}=\int_{q_{i} / T}^{\infty}\left(x T-q_{i}\right) \mathrm{d} \frac{x}{v_{i}}=\frac{1}{2} v_{i} T-q_{i}+\frac{q_{i}^{2}}{2 v_{i} T}, \quad v_{i} T>q_{i} .
$$

With respect to (12), constraint (11) takes the form:

$$
1-\prod_{i=1}^{n} \frac{q_{i}}{v_{i} T}=\varepsilon
$$

Based on (13), we find:

$$
v_{i} T=\frac{-}{2}\left[2 q_{i}+M \Delta_{i}+\sqrt{4 q_{i} M \Delta_{i}+\left(M \Delta_{i}\right)}\right],
$$

Where sign "+" in front of the radical was selected due to condition $v_{i} T>q_{i}$. form:

Then constraint (14) can be represented in the following

$$
\prod_{i=1}^{n} \frac{4 q_{i}}{\mathbf{M} \Delta_{i}+2 q_{i}+\sqrt{4 q_{i} \mathbf{M} \Delta_{i}+\left(\mathbf{M} \Delta_{i}\right)^{2}}}=1-\varepsilon
$$

We will take the logarithms of both parts of equation (16), after which it will take the following form:

$$
\left.\sum_{i=1}^{n}\left\{\ln 4 q_{i}-\ln \left[\mathbf{M} \Delta_{i}+2 q_{i}+\sqrt{4 q_{i} \mathbf{M} \Delta_{i}+(\mathbf{M}} \Delta_{i}\right)^{2}\right]\right\}=\ln (1-\varepsilon) .
$$

After substitution of $M \Delta$ with its expression from formula (7) in the left part of this equation and regrouping its members, we will obtain:

$$
\begin{aligned}
& \sum_{i=1}^{n} \ln 4 q_{i}-\ln (1-\varepsilon)= \\
& =\sum_{i=1}^{n}\left\{\ln \left[a_{i}\left(r_{i}+P_{i}\right)^{-b_{i}}+2 q_{i}+\sqrt{4 q_{i} a_{i}\left(r_{i}+P_{i}\right)^{-b_{i}}+} a_{i}^{2}\left(r_{i}+P_{i}\right)^{-2 b_{i}}\right]\right\} .
\end{aligned}
$$

Thus, the inverse optimization problem can be stated as the problem on the minimization of function (8), subject to constraint (17). This optimization problem applies to the area of convex programming, since, both function (8) and the left part of constraint (17) are the convex functions from $P_{1}, P_{2}, \ldots P_{n}$. Indeed:

$$
\frac{\partial^{2}}{\partial P_{i}^{2}} \bar{B}(\vec{P})=k_{i} a_{i} b_{i}\left(b_{i}+1\right)\left(r_{i}+P_{i}\right)^{-b_{i}-2}>0 .
$$

Similarly, it is easy to verify that the second partial derivative from $P_{i}$ function in the left side of inequality (17) is positive.

The presented model of optimal management of occupational risks for other laws of distribution of random magnitudes $\omega_{i}$ takes also a rather simple form. For example, for the exponential distribution law

$$
F_{i}(x)=1-\exp \left(-x / v_{i}\right), \quad x>0,
$$

where now $v_{i}=\mathbf{M} \omega_{i}$.

Thus, instead of dependence (13), we obtain the following:

$$
\mathbf{M} \Delta_{i}=T v_{i} \exp \left(-q_{i} / v_{i} T\right)
$$

and instead of constraint (14) - the following equality

$$
\prod_{i=1}^{n}\left(1-e^{-q_{i} / T v_{i}}\right)=1-\varepsilon
$$

The presented optimization problems can be solved using both numerical methods and the standard software - Excel package.

\section{Calculation of costs for occupational safety and health for determined occupational risk levels}

Let us explore an example of the case of impact of two harmful production factors on an employee:

- elevated temperature of the working zone $\left(\mathrm{HF}_{1}\right)$;

- elevated level of gas contamination of the air of the working zone $\left(\mathrm{HF}_{2}\right)$.

We will solve, for example, the problem of minimization of function (8) provided (17).

To solve the problem for $\mathrm{HF}_{1}$ and $\mathrm{HF}_{2}$, we used statistical data [14], which are given in Tables 1,2 . The data were acquired from five companies in one industry as of 2016. Accordingly, one number in each row of column 2 and column 3 in Tables 1, 2 is the total value of the indicator of the correspondent enterprise for a year.

Table 1

Source data for the calculation of a model for $\mathrm{HF}_{1}$

\begin{tabular}{|c|c|c|c|}
\hline No. of entry & $\begin{array}{c}B_{21} \text {, thousand } \\
\text { conv. units. }\end{array}$ & $\begin{array}{c}P_{1} \text {, thousand } \\
\text { conv. units. }\end{array}$ & $\begin{array}{c}r_{1}, \text { thousand } \\
\text { conv. units. }\end{array}$ \\
\hline 1 & 11 & 42 & \multirow{2}{*}{} \\
\cline { 1 - 3 } & 12.6 & 39 & \multirow{2}{*}{1.9} \\
\hline 3 & 13 & 37 & \\
\hline 4 & 13.2 & 35 & \\
\hline 5 & 15 & 33 & \\
\hline
\end{tabular}

Table 2

Source data for the calculation of a model for $\mathrm{HF}_{2}$

\begin{tabular}{|c|c|c|c|}
\hline No. of entry & $\begin{array}{c}B_{22} \text {, thousand } \\
\text { conv. units }\end{array}$ & $\begin{array}{c}P_{2} \text {, thousand } \\
\text { conv. units }\end{array}$ & $\begin{array}{c}r_{2} \text {, thousand } \\
\text { conv. units }\end{array}$ \\
\hline 1 & 15.8 & 55 & \multirow{2}{*}{} \\
\cline { 1 - 3 } & 16.9 & 51 & \multirow{2}{*}{9} \\
\hline 3 & 17.6 & 49 & \\
\hline 4 & 18.4 & 47 & \\
\hline 5 & 19.8 & 44 & \\
\hline
\end{tabular}

By employing the least-square method for processing statistical data, the following dependences were obtained:

$$
B_{21}=579.23\left(1.9+P_{1}\right)^{-0,015}, B_{22}=371.56\left(9.6+P_{2}\right)^{-0,671} .
$$

To illustrate the optimization model, we will consider that the intensities of the HF impact has a uniform probability distribution (12). 
The source data for calculation of the problem of minimization of function (8) at constraint (17) are given in Table 3.

Table 3

Source data for solving the optimization problem

\begin{tabular}{|c|c|c|c|c|c|}
\hline $\begin{array}{c}\text { No. of } \\
\text { entry }\end{array}$ & $a_{i}$ & $b_{i}$ & $\begin{array}{c}k_{i} \text {, thou- } \\
\text { sand conv. } \\
\text { units. }\end{array}$ & $q_{i}$ & $\begin{array}{c}r_{i} \text {, thou- } \\
\text { sand conv. } \\
\text { units }\end{array}$ \\
\hline 1 & 579.23 & 1.015 & 1.2 & $26^{\circ} \mathrm{C}$ & 1.9 \\
\hline 2 & 371.56 & 0.671 & 1.1 & $20 \mathrm{mg} / \mathrm{m}^{3}$ & 9.6 \\
\hline
\end{tabular}

Function (8) in this case has the following form:

$$
\bar{B}\left(P_{1}, P_{2}\right)=P_{1}+P_{2}+k_{1} a_{1}\left(r_{1}+P_{1}\right)^{-b_{1}}+k_{2} a_{2}\left(r_{2}+P_{2}\right)^{-b_{2}},
$$

and constraint (17) will be as follows

$$
\begin{aligned}
& 2 \ln 2-\ln q_{1}-\ln q_{2}+ \\
& +\ln \left[a_{1}\left(r_{1}+P_{1}\right)^{-b_{1}}+q_{1}\right]+ \\
& +\ln \left[a_{2}\left(r_{2}+P_{2}\right)^{-b_{2}}+q_{2}\right]=-\ln (1-\varepsilon) .
\end{aligned}
$$

The solutions to the problem of function minimization (18) under condition (19) for different values $\varepsilon$ were obtained using the Microsoft Excel software package (option "Solution search") and are given in Table 4.

Table 4

\section{Calculation results}

\begin{tabular}{|c|c|c|c|c|}
\hline $\begin{array}{c}\text { No. of } \\
\text { entry }\end{array}$ & $\begin{array}{c}P_{1} \text {, thousand } \\
\text { conv. units. }\end{array}$ & $\begin{array}{c}P_{2} \text {, thousand } \\
\text { conv. units. }\end{array}$ & $\begin{array}{c}\text { min } \bar{B}\left(P_{1}, P_{2}\right), \\
\text { thousand conv. } \\
\text { units }\end{array}$ & $\varepsilon$ \\
\hline 1 & 449.96 & 226.488 & 688.3 & 0.01 \\
\hline 2 & 421.645 & 213.607 & 647.601 & 0.02 \\
\hline 3 & 395.69 & 201.731 & 610.275 & 0.03 \\
\hline 4 & 371.833 & 190.756 & 575.956 & 0.04 \\
\hline 5 & 349.868 & 180.58 & 544.341 & 0.05 \\
\hline
\end{tabular}

Table 4 shows that at a decrease at permissible probability of occurrence of a risk event, the costs for occupational health and safety increase as it should have been expected.

\section{Discussion of results of developing a method for the optimal management of occupational risks}

In the framework of the research, both problems that were identified as a result of the conducted analysis and potential situations that were maximally approximated to actual working conditions were taken into account, specifically, random excess in time of boundary permissible concentrations (levels) of harmful production factors in the work zone.

The process of occupational risk management within the framework of the occupational safety management systems is always associated with certain costs, which conditionally can be divided into two groups.

The first group is the costs of implementation and functioning of preventive measures and means of safety $\left(B_{1}\right)$. They include instructions, training, technical safety means, means of individual protection and others.
Within the specified costs, the entity allocates resources $\left(P_{i}, i=1,2, \ldots, n\right)$ to mitigate (eliminate) the negative influence of $n$ kinds of HF.

The second group is related to the costs for eliminating the consequences of an occupational risk, which, despite precautionary measures and means, still exists in the form of damage to the health of an employee $\left(B_{2}\right)$. They can include differential payments to social insurance funds (medical, sanatorium and resort activities etc.). The system of differential payments to the funds, the amount of which is calculated based on the level of occupational risk at a company is progressive and exists virtually in all developed countries of the world. The total costs of these two groups can be considered as the costs of the business entity for occupational safety and health.

A separate group can include the costs of compensation for health damage that are caused by inability to minimize (eliminate) a negative impact on an employee of the $i$-th HF $\left(r_{i}\right)$. These are costs of additional leaves, milk, medical-preventive food, and others.

We believe that within a working shift $(T)$, an employee has a negative influence with random intensity $\omega_{i}$ of several harmful production factors $(n)$. The processes of emergence and duration of a negative impact on an employee are random and independent on each other. Accordingly, the magnitude of the caused damage to the health of an employee can also be considered random.

To minimize such HF, the business entity spends resources $P_{i}, i=1,2, \ldots, n$. The task is to find such values $P$, which would minimize total costs for occupational safety and health (B) at constraint for acceptable level of occupational risk, $\varepsilon$ (criterion of such risk).

With the purpose of solving the task, we stated two optimization problems (8) and (9), which allow maximizing the safety level of an employee at constraint for resources that are allocated for occupational safety.

Calculation of costs for occupational health and safety for determined occupational risk levels was conducted using the Excel package for two harmful occupational factors, specifically, the elevated air temperature of the working zone and increased level of gas contamination of the air of the working area. These factors were taken as an example for testing the possibility of using the developed models in practice. The obtained calculation results indicate that the optimization models are efficient and can be used for a different range of harmful production factors.

In this work, we used the model that establishes dependence of the output parameters on the input data. The instrument for practical implementation of the proposed approach is the standard application Excel. This is very important because it greatly simplifies the process of management of occupational risks, especially for small businesses with limited resource capacities.

The solution of the above problems of optimal control of occupational risk management makes it possible to increase efficiency of functioning of the occupational safety management system through the optimal use of the resources of an enterprise. It will have a positive impact on enhancing occupational safety level, labor productivity and social appeal of an enterprise.

The developed method can be used in all businesses regardless of an industry because the input data for its practical realization are the parameters that are traced, collect- 
ed, and processed within the framework of functioning of existing systems of occupation safety management systems.

The presented optimization models can also be used by funds of social insurance of individuals against accidents and occupational diseases at production enterprises around the world. Using the developed models, it is possible to consider the cases of damage to the health of an employee by the total and separate influence in HF. In the latter case, it is necessary to compare magnitude $\sum_{i=1}^{n} k_{i} \mathbf{M} \Delta_{i}$, which was obtained as a result of solving of one of the two presented optimization problems, with the amount of an insurance premium.

From the formal point of view, the developed optimization models are simplest, though they take into consideration the main factors of occurrence and minimization of occupational risks. The main constraint for practical application of these models is the fact that they are static, that is, not taking into consideration the dynamic nature of processes of contamination of working environment and fluctuation in the concentration of harmful substances in the air and in the organism of an employee.

In subsequent research in a given direction, it is desirable to take into consideration the dynamic nature of the specified processes, which usually have stochastic nature. Specifically, to construct and analyze such models, it is advisable to use the apparatus of Markovian and semi-Markovian processes, which are known to be a flexible mathematical apparatus for studying various natural and industrial processes. For example, in the problem that is explored in this study, the use of Markovian processes will enable taking into consideration a temporary damage to the health of an employee, as a result of the negative impact of different random events that are related to violation of safety requirements or influences of the "human factor", etc.

\section{Conclusions}

1. We conducted an analysis of the international legislation in the field of occupational safety and health and existing methods of occupational risks management at enterprises, which revealed the shortcomings of the existing organization and the methods for effective management of these risks. The main identified shortcomings are:

- uncertainty of the objectives of risk management;

- complexity of performance of the appropriate procedure and its insufficient substantiation;
- lack of available approaches to possibility of the optimal risk management taking in consideration resource capacities of the business entity.

2. The components of the method for the optimal management of occupational risks are:

- costs of the business entity for development and implementation of preventive organizational and technical measures and means of protection of an employee from the effects of $n$ kinds of HF;

- costs of preventive medical and preventive measures for employees exposed to health damage from the influence of HF;

- duration of a working shift;

- random intensity of the impact on an employee of the $i$-th HF;

- financial resources, allocated by the business entity to minimize the impact of the $i$-th HF;

- costs for compensation for health damage that are caused by impossibility to minimize (eliminate) a negative impact on an employee of the $i$-th HF;

- maximum permissible concentration (maximum permissible level) of the $i$-th HF;

- specific costs for treatment of an occupational disease (repairing the damage to the health of an employee);

- specific costs for treatment of an occupational disease (recovery after the damage to the health of an employee);

- actual excess of BPC (BPL) at corresponding costs, allocated for protective measures.

3. Two economic-mathematical models (direct and inverse problems) for optimal management of occupational risks, taking into consideration randomness of the process of influence of harmful production factors on an employee, were developed. The models describe the relations between the probability of occurrence of a risk event and costs of its minimization.

4. The developed mathematical models were tested by calculation on the example of two harmful production factors:

- elevated air temperature of the working zone;

- elevated levels of gas contamination of the air in the working zone.

The calculation results showed that to minimize the acceptable level of occupational risk for the determined range of factors by five times (from 0.01 to 0.05 ), the level of the average estimated cost of occupational safety increases by 1.3 times (from 544.341 thousand of conv. units to 688.3 thousand of conv. units). Conducted testing makes it possible to recommend using the developed models by both business entities, and social insurance funds in the international format.

\section{References}

1. Directive No. 89/391 / EEC of the Council on the introduction of measures to improve the safety and health of workers in the

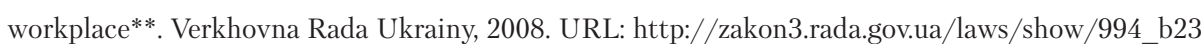

2. Developing a system for the initiation of projects using a Markov chain / Gogunskii V., Bochkovskii A., Moskaliuk A., Kolesnikov O., Babiuk S. // Eastern-European Journal of Enterprise Technologies. 2017. Vol. 1, Issue 3. P. 25-32. doi: 10.15587/1729-4061.2017.90971

3. Świątkowska B. Legal aspects of workers' health protection against asbestos in Poland in the light of the EU legal framework // Medycyna Pracy. 2013. Vol. 64, Issue 5. P. 689-697. doi: 10.13075/mp.5893.2013.0057

4. Bochkovskyi A. P., Sapozhnikova N. Yu., Gogunskii V. D. Legal and organizational issues of improving the labor protection and industrial safety level at the Ukrainian enterprises // Scientific Bulletin of National Mining University. 2017. Issue 5 (161). P. 100-108 doi: 10.13140/rg.2.2.33613.23528

5. Kudryavtsev S. S., Yemelin P. V., Yemelina N. K. The Development of a Risk Management System in the Field of Industrial Safety in the Republic of Kazakhstan // Safety and Health at Work. 2018. Vol. 9, Issue 1. P. 30-41. doi: 10.1016/j.shaw.2017.06.003 
6. Implications of applying cumulative risk assessment to the workplace / Fox M. A., Spicer K., Chosewood L. C., Susi P., Johns D. O., Dotson G. S. // Environment International. 2018. Vol. 115. P. 230-238. doi: 10.1016/j.envint.2018.03.026

7. Anttonen H., Pääkkönen R. Risk Assessment in Finland: Theory and Practice // Safety and Health at Work. 2010. Vol. 1, Issue 1. P. 1-10. doi: 10.5491/shaw.2010.1.1.1

8. Towards dynamic risk analysis: A review of the risk assessment approach and its limitations in the chemical process industry / Villa V., Paltrinieri N., Khan F., Cozzani V. // Safety Science. 2016. Vol. 89. P. 77-93. doi: 10.1016/j.ssci.2016.06.002

9. Rudenko S. V., Postan M. Ya. Metod optimizacii zatrat na prirodoohrannye meropriyatiya pri sluchaynoy intensivnosti zagryazneniya predpriyatiem okruzhayushchey sredy [The method of optimization of costs for environmental protection measures with a random intensity of pollution by the enterprise environment] // Metody ta zasoby upravlinnia rozvytkom transportnykh system. 2011. Issue 17. P. 140-149.

10. Dynamic risk management: a contemporary approach to process safety management / Khan F., Hashemi S. J., Paltrinieri N., Amyotte P., Cozzani V., Reniers G. // Current Opinion in Chemical Engineering. 2016. Vol. 14. P. 9-17. doi: 10.1016/j.coche.2016.07.006

11. Khan F., Rathnayaka S., Ahmed S. Methods and models in process safety and risk management: Past, present and future // Process Safety and Environmental Protection. 2015. Vol. 98. P. 116-147. doi: 10.1016/j.psep.2015.07.005

12. Process Resilience Analysis Framework (PRAF): A systems approach for improved risk and safety management / Jain P., Pasman H. J., Waldram S., Pistikopoulos E. N., Mannan M. S. // Journal of Loss Prevention in the Process Industries. 2018. Vol. 53. P. 61-73. doi: $10.1016 /$ j.jlp.2017.08.006

13. Quantitative risk assessment of continuous liquid spill fires based on spread and burning behaviours / Zhao J., Huang H., Li Y., Jomaas G., Wang H., Zhong M. // Applied Thermal Engineering. 2017. Vol. 126. P. 500-506. doi: 10.1016/j.applthermaleng.2017.07.187

14. The basic statistical data is shown by the economical analytics of the customs agencies EU Countries. URL: http:// ec.europa.eu/eurostat/search?p_auth=QPejFti6\&p_p_id=estatsearchportlet_WAR_estatsearchportlet\&p_p_lifecycle=1\&p_p_ state=maximized\&p_p_mode $=$ view\&_estatsearchportlet_WAR_estatsearchportlet_text $=$ Eurostatistics + DATA + FOR+SHORT-TERM+ECONOMIC+ANALYSIS\&_estatsearchportlet_WAR_estatsearchportlet_sort=_score\&_estatsearchportlet_WAR_estatsearchportlet_action=search\&_estatsearchportlet_WAR_estatsearchportlet_pageNumber=3

15. Bochkovskyi A. P. Teoretychni aspekty universalizatsiyi otsinky profesiynoho ryzyku v systemakh upravlinnya okhoronoyu pratsi [Theoretical aspects of univarsalization of professional risk evolution in occupational health and management systems] // Bulletin of the Lviv State University of Life Safety. 2016. Issue 14. P. 134-151. doi: 10.13140/rg.2.2.22043.87848

16. Plotnikov A. V., Komleva T. A., Plotnikova L. I. The partial averaging of differential inclusions with fuzzy right-hand side // Journal of Advanced Research in Dynamical and Control Systems. 2010. Vol. 2, Issue 2. P. 26-34. URL: https://www.researchgate.net/ publication/285992864_The_partial_averaging_of_differential_inclusions_with_fuzzy_right-hand_side

17. Otradskaya T., Gogunsky V. Development process models for evaluation of performance of the educational establishments // Eastern-European Journal of Enterprise Technologies. 2016. Vol. 3, Issue 3 (81). P. 12-22. doi: 10.15587/1729-4061.2016.66562 